\title{
Pharmacological Evaluation of Cannabis indica For Their Aphrodisiac Potential
}

\author{
Research Article
}

\section{Asheesh Kumar Gupta1*, Anurekha Jain ${ }^{2}$, Partha Roy ${ }^{3}$, Ramandeep Singh4}

\author{
1. Research Scholar, 2. Dean, Department of Pharmacy, \\ Jyoti Vidyapeeth Woman's University Mahela, Jaipur, Rajasthan, India.
}

3. Professor, Department of Biotechnology, Indian Institute of Technology (IIT) Roorkee, Uttarakhand, India. 4. Associate Professor and Head, Himachal Institute of Pharmacy, Paonta Sahib, Himachal Pradesh, India.

\begin{abstract}
Objective: The plant Cannabis indica is a very popular and well known plant across the globe since thousands of years. In India also it is even more popular as bhang or marijuna from ancient time. A quite descriptions of this plant is written in various ancient books like the granths, vedas, puranas, ayurvedic books, dravyaguna, etc.. Number of medicinal properties have been described for different parts of the plant like flower buds(Ganja), Leaf (Bhang) \& Leaf wax (Charas). All the parts of this plant have potent and complex psychotropic properties along with some additional therapeutic actions on different body systems. Here we have fond some opportunities to evaluate herbal extracts of leaves for having aphrodisiac potential. Method: The aphrodisiac activity of Cannabis indica leaf extracts (Pet.ether, methenol \& aqueous) were evaluated in male albino rats. Extracts were administered at a dose of $150 \mathrm{mg} / \mathrm{kg}$ body weight. At an interval of $0,7,14,21 \& 28$ day several sexual behavior parameters were determined. At the end serum testosterone and FSH level were also determined. Results: This study also contributes to the pharmacology of aphrodisiacs as the plant Cannabis indica leaf extracts has significant effects on sexual physiology. It has shown effects on sexual behaviors as well as significant change in gonadotropin hormone labels in animal blood serum. Conclusion: This study provides a strong experimental evidence for its aphrodisiac use.
\end{abstract}

Key Words: Aphrodisiac, Cannabis indica, Herbal aphrodisiacs, Sexual behavior study.

\section{Introduction}

Infertility is one of the major health problems couple's lives; approximately $30 \%$ of couple's infertilities are due to male factors. Around $10-14 \%$ Indian population suffering from infertility. Nearly 27.5 million ones are trying to conceive suffering from infertility in India. WHO estimates that there are 60-80 million infertile couples worldwide.(1) Loss of interest in sex or problems with sexual arousal makes most individuals experience and express discomfort in their sexual behavior. Such concerns or changes may arise from an illness or disability, medication or surgical procedure, changes accompanying the aging process(2), relationship difficulties(3) performance anxiety(4), or a combination of any of these factors. There are three basic types of sexual dysfunction; disorders of desire takes the form of inadequate sexual desire (libido) in both sexes(5) disorders of excitement (or arousal) in men, impotence(6) disorders of orgasm, includes difficulty achieving orgasm in both men and women

\section{* Corresponding Author:}

\section{AsheeshKumar Gupta}

Research Scholar, Department of Pharmacy, Jyoti Vidyapeeth Woman's University Mahela, Jaipur,

Rajasthan, India.

Email Id: guptaasheesh01@gmail.com but more common among men.(7) Libido refers to an individual's desire for sexual activity. This can also be called sex drive. Factors that affect libido include psychological factors, biological factors and social factors. Personality and the level of stress an individual is exposed to be internal psychological factors that can affect sexual desire(8).

Discovery of oral phosphodiesterase type 5(PDE5) inhibitors particularly sildenafil (Viagra), tadalafil (Cialis), and vardenafil (Levitra) has revolutionized treatment of male sexual disorder (MSD).(9) There are many herbal drugs that have been used by men with erectile dysfunction (ED) with varying degrees of success. Most potent herbal aphrodisiacs are available and have little or very little side effects.(10) The Ayurvedic system of medicine addresses the problem of sexual deficiencies by treatment with specialized therapy known as 'Rasayana therapy'. A class of 'Rasayana' or drugs also known as 'Vrishya' or 'Vajikaran Rasayan' has been prescribed debility, especially encountered old age. 'Vajakarna therapy' includes aphrodisiac drugs for erectile dysfunction, reasons of infertility, spermatogenesis, semenogenesis, reproduction, methods of correcting defective semen and sexual satisfaction.(11)

According to traditional information and published text available from various sources a plant Cannabis indica leaves have some active phytochemical entity that we have been proved in our laboratory to exhibit good aphrodisiac potential. 
Cannabis indica Plant belongs to FamilyCannabaceae known as marijuna or bhang. This is a flowering plant that includes three species sativa, indica and ruderalis. The plant is indigenous to central Asia and the Indian subcontinent. Cannabis has long been used for hemp fibre, for hemp oils, for medicinal purposes, and as a recreational drug.Cannabis plants produce a group of chemicals called cannabinoids, which produce mental and physical effects when consumed.(13)

\section{Material and method Plant material}

The leaves of Cannabis indica were collected from Forest Research Institute, Dehradun, Uttarakhand, identified and authenticated by Prof. (Dr.) Rajiv Soni, Botanist \& Centre Head, NIMAPC, Indore, M.P. with the Herbarium Reference No. NIMAPC/CI-161.

\section{Preparation of extracts}

Successive extraction of plant material was done with petroleum ether, methanol and water solvents in our laboratory. The method we used was simple maceration followed by sonication, filtration and evaporation of solvent to get dry extract.

\section{Animals}

Albino wistar rats were procured from IVRI Bareilly (U.P.) and acclimatized in the animal house facility of the department under ambient condition at room temperature $\left(27^{\circ} \mathrm{C} \pm 2^{\circ} \mathrm{C}\right)$ with 12 hour day /night cycle. The animals were provided with pellet feed and free head access to drinking water ad libitum, except during experimentation. Ethical approval was obtained from Institutional Animal Ethical committee IAEC, Dept. of Biotechnology, Indian Institute of Technology(IIT), Roorkee. (BT/IAEC/2018/14).(14)

\section{Pharmacological sexual behavioral study}

The rats were randomly divided in to five groups of 6 animals each. Rats in Group 1 served as vehicle control and received $1 \mathrm{ml}$ of distilled water. Group 2 served as the standard drug control and received sildenafil citrate $5 \mathrm{mg} / \mathrm{kg}$ body weight. Groups3,4 and 5 were treated orally with the plant extracts (1ml) once daily at a dose of $150 \mathrm{mg} / \mathrm{kg}$ body weight respectively. six rats from each group were monitored for sexual behavior study after 1, 3 and 5 daily doses respectively.(15)

\begin{tabular}{|c|c|c|c|}
\hline \multicolumn{3}{|c|}{ Preparation of female rats used in the behavioral study of male rats } & Aphrodisiac study in male rats \\
\hline $\begin{array}{l}48 \text { Hours before } \\
\text { Behavioral Study }\end{array}$ & $\begin{array}{l}6 \text { hours before } \\
\text { behavioral study }\end{array}$ & $\begin{array}{l}1 \text { hours before } \\
\text { behavioral study }\end{array}$ & Male behavioral study \\
\hline $\begin{array}{l}\text { Female rats were injected } \\
\text { with estradiol benzoate } \\
(10 \mu \mathrm{g} / 100 \text { gm) to bring } \\
\text { the animal to estrous } \\
\text { phase }\end{array}$ & $\begin{array}{l}\text { Treated with } \\
\text { progesterone }(0.5 \mathrm{mg} / 100 \\
\text { gm) to bring rats to } \\
\text { estrous phase }\end{array}$ & $\begin{array}{l}\text { Checked for female } \\
\text { responsiveness } \\
\text { (vaginal smear test) }\end{array}$ & $\begin{array}{l}\text { Male rats were exposed to estrous } \\
\text { female for a period of } 30 \text { Minutes and } \\
\text { observed for their sexual behavior } \\
\text { patterns on days } 0,7,14,21 \text { and } 28^{\text {th }} \\
\text { of drug treatment }\end{array}$ \\
\hline
\end{tabular}

- Group I ( Control ): Normal animals treated with 1 $\mathrm{ml} / \mathrm{kg}$, p.o. of saline.

- Group II (Standard drug ): Animals treated with Sildenafil citrate at a dose $5 \mathrm{mg} / \mathrm{kg}$, s.c.

- Group III: Animals treated with petroleum ether extract (PEE) at a dose of $150 \mathrm{mg} / \mathrm{kg}$ (Cannabis indica) p.o.

- Group IV: Animals treated with methanol extract (ME) at a dose of $150 \mathrm{mg} / \mathrm{kg}$ (Cannabis indica) p.o.

- Group V: Animals treated with aqueous extract (AQE) at a dose of $150 \mathrm{mg} / \mathrm{kg}$ (Cannabis indica) p.o.

Male albino rats were distributed into 5 groups consisting of six rats per group.

\section{Evaluation of male sexual behavior}

The animals will be divided into 5 groups each containing 6 animals (albino rats) and all the animals will be housed in individual cages and will be given food and water ad libitum. Sexual behaviour studies will be monitored in a separate room for $30 \mathrm{~min}$. following the administration of standard drug \& extracts and will be given 20 minutes adaptation period, after which a primed female was introduced into the study cage. On days $1,7,14,21$ and $28^{\text {th }}$ sexual behavioural study were monitored. Experiment was performed in the same environment, during dark phase of the day cycle in a large cage $(40 \times 40 \times 40 \mathrm{~cm})$ with a floor that was similar to the home cages. The following male sexual behaviour patterns were recorded:

1. That is the number of mounts in a given period of time(30 min.) or number of mounts in a series.

2. That is the number of intromissions observed in 30 min interval.

3. That is the time interval between the introductions of female to the first mount by male.

4. That is the interval from the time of introduction of female to the first intromission by male.

5. That is the time interval $\mathrm{b} / \mathrm{w}$ the first intromission and ejaculation time.

\section{Attraction towards Female and Determination of Hesitation Time}

A female rat was placed in a cage which has a barrier of $15 \mathrm{~cm}$ separating male \& female compartments which can be passed only by a motivated male rat. The hesitation time was recorded in seconds required by male rat before making an attempt to cross the barrier. In the same way, a scoring for attraction towards female was given as 0 to 5 during an observation period of 15 minutes. A complete cross of the partition by male rat each time was given a score of 5 while an attempt to climb was given a score of $2 \&$ disinterest to climb was rated as 0 . The readings were recorded on $1,7,14,21$ and $28^{\text {th }}$ days of drug treatment. This test is useful in 
determining the willingness of a male rat to cross an aversive or obstructive position, thus indicating the intent of sexual attraction. Male rats of all the groups were subjected to experimentation \& their scores for attraction as well as hesitation time were recorded.

\section{Partner preference test}

Partner preference test was used to evaluate the sexual motivation in no-contact conditions. The apparatus designed to have an open field arena $(100 \mathrm{~cm}$ $X 50 \mathrm{~cm} \mathrm{X} 40 \mathrm{~cm}$ ) with two round cages made of wire mesh of $16 \mathrm{~cm}$ diameter and $40 \mathrm{~cm}$ height diagonally placed at the opposite corners of the arena. We used one pair stimulus animals: a male in one cage and a receptive female in the other cage. The sexual incentive area for female and the social incentive area for male were established. The transmission of olfactory, visual and auditory cues was allowed while mating avoided.

Experimental males were placed for $5 \mathrm{~min}$ individually in the centre of arena. adaptation period given in the presence of stimulus animals and then tested for $10 \mathrm{~min}$. The number of visits to male and female rats, as well as the time spent near each stimulus animal was recorded. The measure of sexual motivation was kept by a preference score, i.e the ratio between the time spent in sexual incentive area and the total time spent in two incentive areas. The readings were recorded on $0,7,14,21$ and $28^{\text {th }}$ days of treatment.

\section{Endocrine tests (Testosterone and FSH assay):}

Blood samples were collected from above animals by retro orbital sinus route. Blood was then centrifuged for $15 \mathrm{~min}$. to obtain serum. It was then stored in dry bottles and frozen for overnight before use. The serum testosterone \& FSH level were quantitatively determined by using the direct human serum testosterone \& FSH ELISA kit (Calbiotech)as the manufacturer's protocol. The principle is the general antibody-antigen reaction based on enzyme linked immunosorbent assay as described. The serum testosterone \& FSH concentration were then interpolated from a standard calibration curve. ${ }^{15}$

\section{Statistical analysis}

Statistical analysis was done by one way ANOVA followed by Dennett's t-test. The values here are expressed in mean values \pm S.E.M. where $n=6$. Notation * means $\mathrm{p}<0.05, * *$ means $(\mathrm{p}<0.01)$, $* * *$ means $(\mathrm{p}<0.001)$; compared to vehicle control group.

\section{Results}

\section{Sexual behavior study}

Several female proceptive and male precopulatory behavior parameters were observed from the cage side when the extract treated male rats were introduced to the receptive female rats. The proceptive behavior displayed by the female rats included earwiggling characterized by a rapid antero-posterior to the male rats (darting) and a short jump with stiff legs followed by immobility and presentation (hopping). The male rats, upon introduction, responded with immediate advances towards the females and displayed precopulatory behavior such as chasing, anogenital sniffing which eventually cuminated into mounting. Lordosis was also displayed by the receptive female rats before, at the beginning and during the mounts. There was genital toileting after every mount that resulted in intromission. The extract produced no sedative effect on the male rats since none of the animals showed evidence of tiredness throughout the observatory period. Aphrodisiac studies in male rats were carried out for 28 days. The following observations were recorded in Cannabis indica leaf extract treated rats.

\section{Effect on Body Weight}

Regular oral administration of Cannabis indica leaf extracts in albino rats exhibited quite increase in their firmness and body weight as the results shown in table -5 .

\section{Effect on serum sex hormone level}

Cannabis indica leaf extracts in albino rats exhibited a quite elevation of serum androgen and regulatory hormone level. The results as described in table-6 demonstrates a significant increase in blood testosterone and Follicle stimulating hormone(FSH) level.

Table-1: Effect of Cannabis indicaleaf extracts on various sexual behavior frequencies in male albino rats

\begin{tabular}{|c|c|c|c|c|c|c|c|}
\hline \multirow{2}{*}{ Test } & \multirow{2}{*}{$\begin{array}{c}\text { Treatment } \\
\text { group }\end{array}$} & \multirow{2}{*}{$\begin{array}{c}\text { Dose } \\
(\mathbf{m g} / \mathbf{k g})\end{array}$} & \multicolumn{5}{|c|}{ Score Mean \pm SEM } \\
\hline & & & 0 day & 7 day & 14 day & 21 day & 28 day \\
\hline \multirow{5}{*}{$\begin{array}{c}\text { Mount } \\
\text { frequency }\end{array}$} & $\begin{array}{l}\text { Vehicle } \\
\text { control }\end{array}$ & $1 \mathrm{ml}$ & $21.62 \pm 1.5$ & $21.62 \pm 1.5$ & $22.82 \pm 1.7$ & $23.12 \pm 0.9$ & $25.62 \pm 2.2$ \\
\hline & Std. control & $5 \mathrm{mg} / \mathrm{kg}$ & $31.76 \pm 1.5^{* * *}$ & $35.58 \pm 2.1^{* * *}$ & $38.62 \pm 1.6^{* * *}$ & $43.23 \pm 1.8^{* * *}$ & $49.07 \pm 2.6^{* * *}$ \\
\hline & CIPEE & 150 & $28.45 \pm 2.3^{* * *}$ & $29.35 \pm 2.8^{* * *}$ & $30.53 \pm 2.4^{* * *}$ & $35.55 \pm 3.3^{* * *}$ & $38.43 \pm 4.2^{* * *}$ \\
\hline & CIME & 150 & $26.65 \pm 2.6^{* * *}$ & $27.24 \pm 2.5^{* * *}$ & $28.68 \pm 4.0^{* * *}$ & $33.32 \pm 1.4^{* * *}$ & $37.64 \pm 2.4^{* * *}$ \\
\hline & CIAQE & 150 & $25.62 \pm 2.4^{* *}$ & $26.45 \pm 3.6^{* *}$ & $27.36 \pm 4.2^{* *}$ & $32.36 \pm 5.2^{* *}$ & $36.27 \pm 2.6^{* *}$ \\
\hline \multirow{5}{*}{$\begin{array}{l}\text { Intromission } \\
\text { frequency }\end{array}$} & $\begin{array}{l}\text { Vehicle } \\
\text { control }\end{array}$ & $1 \mathrm{ml}$ & $7.06 \pm 0.52$ & $7.90 \pm 0.43$ & $8.36 \pm 0.46$ & $8.27 \pm 0.48$ & $8.66 \pm 0.98$ \\
\hline & Std. control & $5 \mathrm{mg} / \mathrm{kg}$ & $9.25 \pm 0.73^{* *}$ & $10.46 \pm 0.88^{* * *}$ & $11.00 \pm 0.25^{*}$ & $12.04 \pm 0.22^{* * *}$ & $13.1 \pm 0.3^{* * *}$ \\
\hline & CIPEE & 150 & $9.38 \pm 0.42^{* *}$ & $10.32 \pm 0.36^{* * *}$ & $11.26 \pm 0.48^{* * *}$ & $12.20 \pm 0.40^{* * *}$ & $13.15 \pm 0.3^{* * *}$ \\
\hline & CIME & 150 & $8.82 \pm 0.72^{* *}$ & $9.65 \pm 0.3^{* *}$ & $11.05 \pm 0.35^{* *}$ & $11.75 \pm 0.26^{* *}$ & $12.75 \pm 0.37^{* *}$ \\
\hline & CIAOE & 150 & $8.25 \pm 0.43^{*}$ & $9.34 \pm 0.24^{* *}$ & $10.53 \pm 0.54^{*}$ & $11.36 \pm 0.69^{*}$ & $12.42 \pm 0.82$ ** \\
\hline
\end{tabular}


Asheesh Kumar Gupta et.al., Pharmacological Evaluation of Cannabis indica For Their Aphrodisiac Potential

\begin{tabular}{l|c|c|c|c|c|c|} 
Vehicle & $1 \mathrm{ml}$ & $2.25 \pm 0.18$ & $2.56 \pm 0.39$ & $2.70 \pm 0.29$ & $3.21 \pm 0.20$ & $2.14 \pm 0.27$ \\
\hline control & & & & & & \\
Std. control & $5 \mathrm{mg} / \mathrm{kg}$ & $2.18 \pm 0.08^{* * *}$ & $2.05 \pm 0.22^{* * *}$ & $2.82 \pm 0.35^{* * *}$ & $3.15 \pm 0.17^{* * *}$ & $3.37 \pm 0.48^{* * *}$ \\
\hline CIPEE & 150 & $2.02 \pm 0.51^{* * *}$ & $2.05 \pm 0.82^{* * *}$ & $2.67 \pm 0.43^{* * *}$ & $2.18 \pm 0.31^{* * *}$ & $2.33 \pm 0.24^{* * *}$ \\
\hline CIME & 150 & $2.22 \pm 0.23^{* * *}$ & $2.21 \pm 0.52^{* * *}$ & $2.89 \pm 0.72^{* * *}$ & $3.28 \pm 0.34^{* * *}$ & $3.45 \pm 0.63^{* * *}$ \\
\hline CIAQE & 150 & $2.28 \pm 0.12^{* * *}$ & $2.50 \pm 0.34^{* * *}$ & $2.86 \pm 0.35^{* * *}$ & $3.12 \pm 0.53^{* * *}$ & $2.16 \pm 0.26^{* * *}$
\end{tabular}

Full form for all the abbreviations denoted et the end.

Values are expressed in mean \pm S.E.M. Where $n=5$ ), $*=p<0.05, * *=p<0.01, * * * p<0.001$; compared with vehicle treated group. Statistical analysis done by one- way ANOVA followed by Dunnett's test.

Table-2: Effect of Cannabis indicaleaf extracts on various sexual behavior latencies in male albino rats

\begin{tabular}{|c|c|c|c|c|c|c|c|}
\hline \multirow{2}{*}{ Test } & \multirow{2}{*}{$\begin{array}{c}\text { Treatment } \\
\text { group }\end{array}$} & \multirow{2}{*}{$\begin{array}{l}\text { Dose } \\
(\mathrm{mg} / \mathrm{kg})\end{array}$} & \multicolumn{5}{|c|}{ Score Mean \pm SEM } \\
\hline & & & o day & 7 day & 14 day & 21 day & 28 day \\
\hline \multirow{5}{*}{ Mount latency } & Vehicle control & $1 \mathrm{ml}$ & $62.71 \pm 1.4$ & $64.43 \pm 2.3$ & $67.31 \pm 0.17$ & $65.23 \pm 0.3$ & $64.26 \pm 1.1$ \\
\hline & Std. control & $5 \mathrm{mg} / \mathrm{kg}$ & $64.89 \pm 2.3^{* * *}$ & $58.34 \pm 0.4^{* * *}$ & $54.33 \pm 1.2^{* * *}$ & $45.75 \pm 0.5^{* * *}$ & $36.56 \pm 1.3^{* * *}$ \\
\hline & CIPEE & 150 & $60.24 \pm 2.6^{* * *}$ & $58.46 \pm 0.5^{* * *}$ & $55.22 \pm 0.6^{* * *}$ & $44.40 \pm 0.8^{* * *}$ & $37.34 \pm 1.4^{* * *}$ \\
\hline & CIME & 150 & $61.21 \pm 6.3^{* * *}$ & $58.25 \pm 0.4^{* * *}$ & $57.24 \pm 1.3^{* *}$ & $46.42 \pm 0.5^{* *}$ & $38.23 \pm 1.5^{* *}$ \\
\hline & CIAQE & 150 & $62.03 \pm 3.5^{* *}$ & $60.50 \pm 0.68^{* *}$ & $58.72 \pm 0.6^{* *}$ & $47.41 \pm 0.7^{* *}$ & $42.24 \pm 0.44^{* *}$ \\
\hline \multirow{5}{*}{$\begin{array}{l}\text { Intromission } \\
\text { latency }\end{array}$} & Vehicle control & $1 \mathrm{ml}$ & $165 \pm 3.9$ & $170 \pm 5.1$ & $164.4 \pm 8.5$ & $171 \pm 4.3$ & $166.8 \pm 3.5$ \\
\hline & Std. control & $5 \mathrm{mg} / \mathrm{kg}$ & $189.6 \pm 4.1^{* * *}$ & $176 \pm 5.1^{* * *}$ & $150.2 \pm$ & $121 \pm 3.8^{* * *}$ & $119.5 \pm 6.7^{* * *}$ \\
\hline & CIPEE & 150 & $153.6 \pm 2.5^{* * *}$ & $148 \pm 3.3^{* * *}$ & $142 \pm 3.4^{* * *}$ & $136 \pm 3.2^{* *}$ & $118.2 \pm 1.2^{* * *}$ \\
\hline & CIME & 150 & $158 \pm 2.4^{* * *}$ & $152 \pm 3^{* * *}$ & $144 \pm 3.2^{* * *}$ & $138 \pm 2.3^{* * *}$ & $120 \pm 2.4^{* * *}$ \\
\hline & CIAQE & 150 & $162 \pm 4.7^{* *}$ & $154 \pm 3.7^{* * *}$ & $147 \pm 2.2^{* * *}$ & $140 \pm 2.5^{* * *}$ & $123 \pm 3.6^{* * *}$ \\
\hline \multirow{5}{*}{$\begin{array}{l}\text { Ejaculation } \\
\text { latency }\end{array}$} & Vehicle c & $1 \mathrm{ml}$ & & & & & $8.55 \pm 0.22$ \\
\hline & Std. control & $5 \mathrm{mg} / \mathrm{kg}$ & $8.85 \pm 0.8^{* * *}$ & $9.50 \pm 0.3^{* * *}$ & $10.33 \pm 0.5^{* * *}$ & $10.54 \pm 0.2^{* * *}$ & $10.75 \pm 0.2^{* * *}$ \\
\hline & CIPEE & 150 & $8.54 \pm 0.5^{* * *}$ & $8.26 \pm 0.4^{* * *}$ & & $9.4 \pm 0.6^{* * *}$ & $10.5 \pm 0.4^{* * *}$ \\
\hline & CIME & 150 & $8.26 \pm 0.4^{* *}$ & $8.12 \pm 1.2^{* *}$ & $9.24 \pm 0.3^{* *}$ & $8.5 \pm 0.5^{* *}$ & $9.6 \pm 1.5^{* *}$ \\
\hline & CIAQE & 150 & 8.62 & & & & $9.4 \pm 0.4^{* *}$ \\
\hline \multirow{5}{*}{$\begin{array}{c}\text { Postejaculatory } \\
\text { pause }\end{array}$} & Vehicle co & $1 \mathrm{ml}$ & $8.4 \pm 0.19$ & $8.5 \pm 0.35$ & $8.8 \pm 0.35$ & $8.5 \pm 0.21$ & $7.9 \pm 0.23$ \\
\hline & Std. control & $5 \mathrm{mg} / \mathrm{kg}$ & $5.6 \pm 0.33^{* * *}$ & $5.7 \pm 0.40^{* * *}$ & $4.8 \pm 0.35^{* * *}$ & $4.4 \pm 0.39^{* * *}$ & $4.3 \pm 0.36^{* * *}$ \\
\hline & CIPEE & 150 & $5.4 \pm 0.42^{* * *}$ & $5.5 \pm 0.21^{* * *}$ & $4.6 \pm 0.46^{* * *}$ & $5.1 \pm 0.25^{* * *}$ & $4.4 \pm 0.44^{* * *}$ \\
\hline & CIME & 150 & $5.8 \pm 0.48^{* * *}$ & $6.10 \pm 0.32^{* * *}$ & $4.9 \pm 0.34^{* * *}$ & $5.6 \pm 0.43^{* * *}$ & $4.8 \pm 0.52^{* * *}$ \\
\hline & CIAQE & 150 & $6.2 \pm 0.32^{* *}$ & $6.62 \pm 0.3^{* *}$ & $5.4 \pm 0.45^{* *}$ & $6.2 \pm 0.45^{* *}$ & $5.5 \pm 0.33^{* *}$ \\
\hline
\end{tabular}

Values are expressed in mean \pm S.E.M. Where $\mathrm{n}=5$ ), $*=\mathrm{p}<0.05, * *=\mathrm{p}<0.01, * * * \mathrm{p}<0.001$; compared with vehicle treated group. Statistical analysis done by one- way ANOVA followed by Dunnett's test.

Table-3: Effect of Cannabis indica leaf extracts on Hesitation time and Cumulative score for attraction towards female in male albino rats

\begin{tabular}{|c|c|c|c|c|c|c|}
\hline \multirow{2}{*}{ Test } & \multirow{2}{*}{ Treatment } & \multirow{2}{*}{$\begin{array}{c}\text { Dose } \\
\text { (mg/kg) }\end{array}$} & \multicolumn{4}{|c|}{ Score $($ Mean \pm SEM) } \\
\hline & & & 7 & 14 & 21 & 28 \\
\hline \multirow{5}{*}{$\begin{array}{l}\text { Hesitation time } \\
\text { in sec. }\end{array}$} & Vehicle control & $1 \mathrm{ml}$ & $340 \pm 12.25$ & $343 \pm 22.5$ & $332 \pm 22.2$ & $341 \pm 13.4$ \\
\hline & Std. control & $5 \mathrm{mg} / \mathrm{kg}$ & $219 \pm 5.22^{* * *}$ & $199 \pm 12.12^{* * *}$ & $172 \pm 12.10^{* * *}$ & $180 \pm 12.04^{* * *}$ \\
\hline & CIPEE & 150 & $235 \pm 7.24^{* * *}$ & $186 \pm 5.2^{* * *}$ & $195.6 \pm 11.3^{* * *}$ & $193 \pm 8.2^{* * *}$ \\
\hline & CIME & 150 & $246 \pm 12.2^{* * *}$ & $222 \pm 8.4^{* * *}$ & $218 \pm 10.3^{* * *}$ & $227 \pm 4.30^{* * *}$ \\
\hline & CIAQE & 150 & $251 \pm 8.3^{* * *}$ & $228 \pm 9.8^{* * *}$ & $227 \pm 5.15^{* * *}$ & $232 \pm 7.41^{* * *}$ \\
\hline \multirow{5}{*}{$\begin{array}{c}\text { Attraction } \\
\text { towards female }\end{array}$} & Vehicle control & $1 \mathrm{ml}$ & $19.22 \pm 3.1$ & $21.61 \pm 3.2$ & $27 \pm 30.22$ & $30.70 \pm 1.35$ \\
\hline & Std. control & $5 \mathrm{mg} / \mathrm{kg}$ & $35.2 \pm 5.04^{* * *}$ & $38 \pm 3.4^{* * *}$ & $64.70 \pm 3.4^{* * *}$ & $84.23 \pm 1.3^{* * *}$ \\
\hline & CIPEE & 150 & $34.14 \pm 4.3^{* * *}$ & $47 \pm 5.4^{* * *}$ & $59.21 \pm 3.1^{* * *}$ & $82.61 \pm 4.74^{* * *}$ \\
\hline & CIME & 150 & $32.51 \pm 4.4^{* * *}$ & $35.4 \pm 1.6^{* * *}$ & $41.61 \pm 1.3^{* * *}$ & $68.61 \pm 5.0^{* * *}$ \\
\hline & CIAQE & 150 & $27.21 \pm 4.3^{* * *}$ & $29.3 \pm 2.4^{* * *}$ & $35.24 \pm 2.8^{* * *}$ & $48.21 \pm 3.72^{* * *}$ \\
\hline
\end{tabular}

Values are expressed in mean \pm S.E.M. Where $n=5$ ), $*=\mathrm{p}<0.05, * *=\mathrm{p}<0.01, * * * \mathrm{p}<0.001$; compared with vehicle treated group. Statistical analysis done by one- way ANOVA followed by Dunnett's test.

Table -4: Effect of Cannabis indica extract on partner preference test in male albino rats

\begin{tabular}{c|c|c|c|} 
S. No. & Treatment & $\begin{array}{c}\text { Dose } \\
(\mathbf{m g} / \mathbf{k g})\end{array}$ & $\begin{array}{c}\text { Partner preference test } \\
\text { (Mean } \pm \text { SEM) }\end{array}$ \\
\hline 1 & 28 days \\
\hline 2 & Control & $1 \mathrm{ml}$ & $0.87 \pm 0.01$ \\
3 & Standard & $5 \mathrm{mg} / \mathrm{kg}$ & $0.98 \pm 0.07^{* * *}$ \\
4 & $C I P E E$ & 150 & $0.97 \pm 0.02^{* * *}$ \\
5 & $C I M E$ & 150 & $0.92 \pm 0.03^{* *}$ \\
\hline
\end{tabular}

Values are expressed in mean \pm S.E.M. Where $\mathrm{n}=5$ ), $*=\mathrm{p}<0.05, * *=\mathrm{p}<0.01, * * * \mathrm{p}<0.001$; compared with vehicle treated group. Statistical analysis done by one- way ANOVA followed by Dunnett's test. 
International Journal of Ayurvedic Medicine, Vol 11 (3), 399-404

Table-5: Effect of Cannabis indica extract on Body weight of albino rats

\begin{tabular}{|c|c|c|c|c|c|c|}
\hline \multirow{2}{*}{ S. No. } & \multirow{2}{*}{ Treatment } & \multirow{2}{*}{$\begin{array}{c}\text { Dose } \\
(\mathrm{mg} / \mathrm{kg})\end{array}$} & \multicolumn{4}{|c|}{ Average Body Weight Of Rats In Grams (Mean \pm SEM) } \\
\hline & & & 7 & 14 & 21 & 28 \\
\hline 1 & Control & $1 \mathrm{ml}$ & 312.22 & 318.27 & 324.73 & 327.08 \\
\hline 2 & Standard & $5 \mathrm{mg} / \mathrm{kg}$ & 308.72 & 314.33 & 318.43 & $322.48^{*}$ \\
\hline 3 & CIPEE & 150 & 309.25 & 311.24 & 316.34 & 317.32 \\
\hline 4 & CIME & 150 & $320.34 *$ & 322.16 & $323.22 *$ & $328.5^{*}$ \\
\hline 5 & CIAQE & 150 & $318.43 *$ & 320.21 & $323.32 *$ & $325.24 *$ \\
\hline
\end{tabular}

vehicle treated group. Statistical analysis done by one- way ANOVA followed by Dunnett's test.

Table-6: Effect of Cannabis indica extract on serum testosterone \& FSH level in albino rats

\begin{tabular}{|c|c|c|c|}
\hline Test & Treatment & $\begin{array}{c}\text { Dose } \\
\text { (mg/kg) }\end{array}$ & $\begin{array}{c}\text { Serum hormone Levels } \\
\text { (Mean } \pm \text { SD) } \\
\text { 28th day }\end{array}$ \\
\hline \multirow{5}{*}{ Testosterone (ng/ml) } & Vehicle control & $1 \mathrm{ml}$ & 0.78 \\
\hline & Standard & $5 \mathrm{mg} / \mathrm{kg}$ & $0.85^{* *}$ \\
\hline & CIPEE & 150 & $0.88 * *$ \\
\hline & CIME & 150 & $0.83 * *$ \\
\hline & $C I A Q E$ & 150 & $0.84 * *$ \\
\hline \multirow{5}{*}{ FSH (mIU/ml) } & Vehicle control & $1 \mathrm{ml}$ & 10.52 \\
\hline & Standard & $5 \mathrm{mg} / \mathrm{kg}$ & $11.45^{* *}$ \\
\hline & CIPEE & 150 & $12.40 * * *$ \\
\hline & CIME & 150 & $12.20^{* *}$ \\
\hline & CIAQE & 150 & $11.13^{*}$ \\
\hline
\end{tabular}

Values are expressed in mean \pm S.E.M. Where $\mathrm{n}=5), *=\mathrm{p}<0.05, * *=\mathrm{p}<0.01, * * * \mathrm{p}<0.001$; compared with vehicle treated group. Statistical analysis done by one- way ANOVA followed by Dunnett's test.

\section{Discussion}

\section{Sexual behavior study}

The present study clearly provides evidence for the ability of Cannabis indica leaf extractsto enhance sexual behavior and performance in male albino rats. The experimental data reveals that oral administration of leaf extracts Pet. ether, methenol \& aqueous (150mg/ $\mathrm{kg}$ Body wt.), possess effective improvement in several copulatory behavior parameters, body firmness and blood androgen levels. Sildenafil citrate $(5 \mathrm{mg} / \mathrm{kg})$ was used as a standard drug to compare our test results for the level of significance.

Petroleum ether extract produced a significant increase $(\mathrm{P}<0.001)$ as compared to vehicle control group in Mount frequency (MF), Intromission frequency (IF) \& Ejaculation frequency (EF) on 0, 7, 14, 21 and $28^{\text {th }}$ day in male Rats. Methanolic and aqueous extracts also produced significant increase $(\mathrm{P}<0.01)$ in these parameters. The expression of MF as libido, IF as potency and EF as duration of coitus considered. (Table-1)

Petroleum ether extract treated rats also showed significant decrease $(\mathrm{P}<0.001)$ as compared to vehicle control group in mount latency (ML), intromission latency (IL) and ejaculation latency(EL) from 0 day till $28^{\text {th }}$ day in male rats. Methanolic and aqueous extracts also produced significant decrease $(\mathrm{P}<0.01)$ in these parameters. Similarly all the extracts exhibited decreasing effects $(\mathrm{P}<0.01 \& 0.001)$ on Post ejaculatory Mount latency \& hesitation time. (Table-2\&3)

It has been observed that Petroleum ether extract treated rats showed significant increase $(\mathrm{P}<0.001)$ as compared to vehicle control group in attraction towards female from 0 day till $28^{\text {th }}$ day of treatment. Methanolic and aqueous extracts also produced significant increase $(\mathrm{P}<0.01)$ in these parameters. Corresponding significant decrease $(\mathrm{P}<0.001$ as compared to vehicle control group $)$ in cumulative score for Partner preference test was observed in all extracts in potency order of CIPEE $>$ CIME $>$ CIAQE. (Table-4)

\section{Body weight}

A significant increase in body weight of all Cannabis indicaleaf extract treated animals was recorded. As the dose and duration was increasing, firmness of body was improving for some instance then it become stable. An increase of about $4.8 \%$ in group-1 $(\mathrm{p}<0.05), 4.54 \%$ in group- $2(\mathrm{p}<0.05), 2.56 \%$ in group-3( $\mathrm{p}<0.05), 2.6 \%$ in group- $4(\mathrm{p}<0.05) \& 2.2 \%$ in group-5(p<0.05) was observed in 4 weeks. The body weight was constantly increasing.(Table-5)

\section{Serum androgen levels in rats}

Serum testosterone and FSHlevel was significantly increased in extract treated animals compared to vehicle control group animals. There was a regular increase in testosterone level $\mathrm{b} / \mathrm{w}$ the readings at weekly intervals. In group $3,4 \& 5$ the level of significance was found to be $p<0.01$.(Table-6)(16-19)

\section{Conclusion}

In conclusion, the drug Cannabis indica leaf extracts demonstrated aphrodisiac properties inin-vivo albino wistar rat models. Sexual behavior study parameters reveals and confirmed this drug extracts as a potent aphrodisiac aid. A significant increase in sexual activities and decrease in several latency periods proves it as well as the result outcomes of serum endocrine analysis also confirming its aphrodisiac potential. This 
Asheesh Kumar Gupta et.al., Pharmacological Evaluation of Cannabis indica For Their Aphrodisiac Potential

drug or its preparations would help peoples with sex related problems and performances.

\section{Abbreviations}

CIPEE-Cannabis indica petroleum ether extract

CIME- Cannabis indica Methanolic extract

CIAQE-Cannabis indica aqueous ectract

\section{Acknowledgement}

We would like to thank Jyoti Vidyapeeth Woman's University Mahela, Jaipur and Department of Biotechnology, IIT Roorkee for their valuable support and guidance and laboratory facilities.

- Conflict of interest: We declare that we have no conflict of interest. The authors alone are responsible for the content and writing of the paper.

- Financial Support: Nil

\section{References}

1. Isidori A, Medical treatment to improve sperm quality. J Reprod Biomed. 2006. 12: 704- 714.

2. Asheesh Kumar Gupta, Anurekha Jain, Ramandeep Singh, Aphrodisiac: An Overview in Present Context of Ailment , Asian Pac. J. Health Sci., 2019. 6(2):184-193.

3. Carroll J. L., Ellis D. J., Bagley D. H., Age-related changes in hormones in impotent men. Jefferson Sexual Function Center. Urology. 1996. 36: 42-60.

4. Clement U., Sex in long-term relationships: a systemic approach to sexual desire problems. Arch Sex Behav. 2002. 31(3) 241-6.

5. Barlow H. D., Causes of sexual dysfunction: The role of anxiety and cognitive interference. J Consult Clin Psychol 1986. 54:140-148

6. Singh R, Gupta A, Jain A, Kakar S., Traditional medicinal plants as scientifically proven aphrodisiacs, International Journal of Health and Biological Sciences. 2018. 1(1):29-36.

7. Meana M., Binik Y.M., Khalif S., Cohen D., Dyspareunia: sexual dysfunction or pain syndrome? J. Nerv. Ment. Dis.1997. 185: 561-9.

8. Basson R., Rethinking low sexual desire in women. Br. J. Obstet. Gynecol.2002. 109: 357-63
9. Sleator R. D., Prediction of Protein Functions. Methods in Molecular Biology, 2012. 815: 15-24'

10. M. T. Yakubu, M. A. Akanji, A. T. Oladiji, Aphrodisiac potentials of the aqueous extract of Fadogia agrestis (Schweinf. Ex Hiern) stem in male albino rats., Asian J. Androl., 2005.7 (4): 399-404.

11. Pallavi K.J., Ramandeep S., Sarabjeet S., Karam S., Mamta F., Vinod S., Aphrodisiac agents from medicinal plants: A review. J Chem Pharm Res.,2011. 3(2): 911-921.

12. WHO. Traditional Medicine Strategy, World Health Organization: Geneva, Switzerland, 2002-2005.

13. Mahlberg Paul G., Soo Kim Eun., "THC (tetrahyrdocannabinol) accumulation in glands of Cannabis (Cannabaceae)". The Hemp Report.2001. 3(17):1.

14. Semwal A, Kumar M, Development of quality control parameters for the standardization of Leaves and bark of Sida acuta Burm.f. Indian Journal of Pharmaceutical and Biological Research, 2014. 2(4); 89-93.

15. Singh R, Ali A, Jeyabalan G, Semwal A. Jaikishan. An overview of the current methodologies used for evaluation of aphrodisiac agents. J of Acute Dis., 2013. 2(2):85-91.

16. Chauhan NS, Dixit VK., Effects of Bryonia laciniosa seeds on sexual behaviour of male ratsInternational. J Impot Res., 2010. 22:190-5

17. Asuntha G, Prasanna Raju Y, Harini Chowdary V, Vandana KR, Arun Rasheed, Prasad KVSRG., Pharmacological profiling of Argemone mexicana for its aphrodisiac potentials in male Wistar rats, Asian Pacific Journal of Reproduction, 2014. 3(2):110-115.

18. Zhang, Y., Zhou, F. \&amp; Ge, F., Effects of combined extracts of Lepidium meyenii and Allium tuberosum Rottl. on erectile dysfunction. BMC Complement Altern Med., 2019. 19:135.

19. RB. Gupta, A. Ahuja, MP. Kabra, S. Soni., Study of Fenugreek Effect on Aphrodisiac Activity in Diabetes Induced Rat, Int. J. Pharm. Med. Res., 2015. 3(3):232-237. 